\title{
Psychosocial implications of recurrent genital herpes simplex virus infection
}

\author{
DAVID GOLDMEIER, ${ }^{*}$ ANTHONY JOHNSON, $†$ MICHELENE BYRNE, ${ }^{*}$ \\ SIMON BARTON* \\ From the *Praed Street Clinic, St Mary's Hospital, London, and the †MRC Biostatistics Unit, Cambridge
}

SUMMARY Fifty seven patients experiencing first attacks of genital herpes simplex virus infection (HSVI) were compared with 50 patients who were concerned about frequently recurring attacks despite routine counselling and reassurance. Using the general health questionnaire this latter group was found to be more psychologically distressed and more socially naive than the first attack group, as measured by socioeconomic class and the lie score of the Eysenck personality questionnaire; otherwise the two groups were similar. Patients presenting to clinics with frequently recurring genital HSVI may therefore be especially psychologically distressed, socially naive, and disadvantaged. Managing these patients needs to include understanding these problems as well as giving advice and using antiviral agents.

The physical complications of genital herpes simplex virus infection (HSVI) include the transmission of infection to the neonate and possibly cervical carcinoma.' The risk of neonatal transmission is only $5 \%$, even with a proved cervical recurrence at the time of delivery. ${ }^{2}$ This figure may be further reduced by the careful obstetric management of delivery. Cervical cytological screening with appropriate colposcopic examination can be used to detect cervical precancer, although HSVI is currently only thought to play a secondary role in the aetiology of cervical neoplasia. ${ }^{3}$ In addition to these potential complications in women, recurrent infections occur at a mean rate of between 0.09 and 0.4 a month. ${ }^{4}$

Despite reassurance by health care workers, genital HSVI is not usually seen by patients to be an essentially benign condition. Indeed, many patients are psychologically devastated by recurrences. They complain that they are stigmatised by having a chronic sexually transmitted disease, ${ }^{5}$ though other patients are relatively unaffected and lead normal lives. It is not clear why this difference should exist. We therefore set out to examine whether coexistent psychiatric illness or personality traits and their wider social implications are associated with frequent recurrences of genital HSVI in patients who cannot come to terms with the diagnosis, despite counselling and reassurance.

Address for reprints: Dr D Goldmeier, Praed Street Clinic, St Mary's Hospital, London W2 IPG

Accepted for publication 20 January 1988

\section{Patients and methods}

We saw 57 patients with culture proved, clinically apparent, first attack genital HSVI who attended the Praed Street Clinic in January to December $1983 .{ }^{6}$ All the 16 men included suffered from penile HSVI; three were homosexual and 13 heterosexual. None of the men had clinical signs of AIDS or AIDS related disease. None was tested for antibody to human immunodeficiency virus (HIV).

At the time of the first attack, patients were treated with one of the following: a five day course of systemic acyclovir, a local antiviral cream (Arildone, Winthrop WIN 38020), inert placebo cream, or no medication. All were followed up until their first subjective recurrence, when they attended again for clinical and virological assessment.

The 50 patients with recurrent infection were seen in the same clinic in July 1984 to June 1985 . Homosexual men who had not been monogamous since 1980 or who had anal HSVI were excluded. The one male homosexual in the group had no clinical signs of AIDS or AIDS related disease, but was not tested for antibody to HIV. Patients who had suffered one or more recurrences of genital HSVI a month during the previous three months and were concerned about this, despite routine counselling and reassurance by a clinician, were invited to attend a special "herpes clinic". None was taking acyclovir or any immunomodulating agents.

Recurrent genital HSVI was confirmed in every case in both groups by clinical examination or, when 
Table 1 Social class of 107 patients with genital herpes simplex virus ( $H S V)$ infection

\begin{tabular}{lcc}
\hline Social class & $\begin{array}{l}\text { First attack } \\
(n=57)\end{array}$ & $\begin{array}{l}\text { Recurrence } \\
(n=50)\end{array}$ \\
\hline I & 7 & 6 \\
II & 33 & 16 \\
III & 7 & 24 \\
IV & 7 & 3 \\
V & 3 & 1 \\
\hline
\end{tabular}

possible, by isolating the virus in cell culture with subsequent typing using a fluorescent labelled monoclonal antibody test. Both groups of patients were assessed for demographic details. The nature of the study was explained to all patients, who gave their verbal consent. All were aged 16 or more, and none of the patients studied after having first attacks entered the recurrence study. Each patient completed a 60 item general health questionnaire (GHQ) and the Eysenck personality questionnaire (EPQ) ${ }^{78}$

The scores on five scales (GHQ and EPQ extroversion, neuroticism, psychoticism, and lie) were transformed by taking the square root of the sum plus one before being analysed by a three factor analysis of variance. The distributions of social classes in the two groups of patients were compared using the $\chi^{2}$ test (social classes 4 and 5 having been combined).

\section{Results}

Of the 57 patients experiencing first attacks of HSVI (median age 22.4, range 18 to 43 ), 16 were men and 41 women. Of the 50 with recurrences (median age 28.5, range 21-42), 21 were men and 29 women. The recurrence group thus had a higher proportion of men and was slightly older than the first attack group. Table 1 shows that social class was higher in patients experiencing first attacks $\left(\chi^{2}=17.5, \mathrm{df}=3, \mathrm{p}<\right.$ 0.001 ), mainly because they included a preponderance of patients belonging to classes II and III.

HSV biotype was tested in 34 patients with first attacks and 19 patients with recurrences. Type 1 was found in eight of the first attack group but none of the recurrent group, whereas type 2 was found in 26 patients with first attacks and 29 with recurrences.

All except four of the recurrent group had suffered their first infection more than a year before the study began; 19 had suffered from recurrence for longer than three years. Sixteen of the patients. with recurrences were experiencing sexual difficulties with current partners.

Table 2 shows back transformed mean GHQ and EPQ scores with $95 \%$ confidence limits. The neuroticism scores showed no important differences between the groups, sexes, or social classes. The psychoticism scores, however, were higher in men $(F=4.98$;

Table 2 Scores in general health questionnaire (GHQ) and Eysenck personality questionnaire (EPQ) for patients with first and recurrent attacks of genital herpes simplex virus infection

\begin{tabular}{|c|c|c|c|c|}
\hline \multirow[b]{2}{*}{ Psychology scale } & \multicolumn{2}{|l|}{ First attack: } & \multicolumn{2}{|l|}{ Recurrences: } \\
\hline & $\operatorname{Men}(n=14)$ & Women $(n=39)$ & $\operatorname{Men}(n=21)$ & Women $(n=29)$ \\
\hline $\begin{array}{l}\text { GHQ score: } \\
\text { Median } \\
\text { Range } \\
\text { Mean } \\
95 \% \text { confidence interval }\end{array}$ & $\begin{array}{l}4 \cdot 0 \\
0-28 \\
5 \cdot 1 \\
1 \cdot 5-10 \cdot 1\end{array}$ & $\begin{array}{l}17 \cdot 0 \\
0-42 \\
14 \cdot 4 \\
10 \cdot 5-18 \cdot 7\end{array}$ & $\begin{array}{l}13 \cdot 0 \\
0-45 \\
12 \cdot 4 \\
7 \cdot 7-18 \cdot 1\end{array}$ & $\begin{array}{l}17 \cdot 0 \\
0-50 \\
15 \cdot 9 \\
11 \cdot 3-21 \cdot 2\end{array}$ \\
\hline $\begin{array}{l}\text { EPQ extroversion score: } \\
\text { Median } \\
\text { Range } \\
\text { Mean } \\
\text { 95\% confidence interval }\end{array}$ & $\begin{array}{l}14 \cdot 0 \\
1-20 \\
12 \cdot 6 \\
9 \cdot 7-15 \cdot 8\end{array}$ & $\begin{array}{l}14 \cdot 8 \\
0-21 \\
12 \cdot 8 \\
11 \cdot 1-14 \cdot 7\end{array}$ & $\begin{array}{l}15 \cdot 0 \\
5-20 \\
13 \cdot 7 \\
11 \cdot 3-16 \cdot 4\end{array}$ & $\begin{array}{l}16 \cdot 0 \\
1-21 \\
13 \cdot 8 \\
11 \cdot 7-16 \cdot 1\end{array}$ \\
\hline $\begin{array}{l}\text { EPQ neuroticism score: } \\
\text { Median } \\
\text { Range } \\
\text { Mean } \\
\text { 95\% confidence interval }\end{array}$ & $\begin{array}{l}11 \cdot 3 \\
3-19 \\
10 \cdot 6 \\
7 \cdot 8-13 \cdot 7\end{array}$ & $\begin{array}{l}14 \cdot 4 \\
2-23 \\
13 \cdot 1 \\
11 \cdot 2-15 \cdot 2\end{array}$ & $\begin{array}{l}11 \cdot 0 \\
2-23 \\
11 \cdot 6 \\
9 \cdot 2-14 \cdot 3\end{array}$ & $\begin{array}{l}12 \cdot 0 \\
1-21 \\
11 \cdot 3 \\
9 \cdot 2-13 \cdot 5\end{array}$ \\
\hline $\begin{array}{l}\text { EPQ psychoticism score: } \\
\text { Median } \\
\text { Range } \\
\text { Mean } \\
95 \% \text { confidence interval }\end{array}$ & $\begin{array}{l}4 \cdot 5 \\
0-14 \\
4 \cdot 7 \\
3 \cdot 1-6 \cdot 4\end{array}$ & $\begin{array}{l}4 \cdot 5 \\
0-11 \\
3 \cdot 8 \\
2 \cdot 9-4.8\end{array}$ & $\begin{array}{l}5 \cdot 0 \\
1-14 \\
5 \cdot 3 \\
3 \cdot 9-6 \cdot 7\end{array}$ & $\begin{array}{l}3 \cdot 8 \\
1-9 \\
3 \cdot 4 \\
2 \cdot 4-4 \cdot 5\end{array}$ \\
\hline $\begin{array}{l}\text { EPQ lie score: } \\
\text { Median } \\
\text { Range } \\
\text { Mean } \\
95 \% \text { confidence interval }\end{array}$ & $\begin{array}{l}5 \cdot 0 \\
1-9 \\
4 \cdot 8 \\
3 \cdot 2-6 \cdot 5\end{array}$ & $\begin{array}{l}6 \cdot 5 \\
0-15 \\
5 \cdot 9 \\
4 \cdot 9-7 \cdot 0\end{array}$ & $\begin{array}{l}5 \cdot 4 \\
0-18 \\
5 \cdot 6 \\
4 \cdot 2-7 \cdot 0\end{array}$ & $\begin{array}{l}8 \cdot 0 \\
3-15 \\
8 \cdot 4 \\
7 \cdot 0-9 \cdot 8\end{array}$ \\
\hline
\end{tabular}

* Means back transformed after taking square root of $(x+1)$ transformation of raw data. 
$\mathrm{df}=1.87 ; \mathrm{p}=0.028)$. The extroversion scores showed a complex interaction for all three variables $(F=3 \cdot 11$; df $=3.87 ; p=0.031$ ) which was predominantly due to a low score in the one woman of low social class in the recurrence group, although overall there were no consistent differences. The GHQ scores were higher in women than men $(F=8.26 ; \mathrm{df}=1.87 ; \mathrm{p}=0.005)$ and also higher in patients with recurrences than with first episodes $(F=5.07 ; d f=1.87 ; p=0.027)$. The lie scale showed an interaction between sex and social class, which arose from men scoring higher than women in social class III but lower in other social classes, with the recurrence group scoring higher overall $(F=8.53$; df $=1.87 ; p=0.004$ ).

To check that these differences in the lie scales were independent of those in the GHQ scale, the analysis of variance of the transformed lie scores was repeated with the transformed GHQ as a covariate. There was no apparent association between the two scores $(F=$ $0.13 ; \mathrm{df}=1.86 ; \mathrm{p}=0.72$ ), and after adjustment for GHQ there was still a sex by social class interaction $(F$ $=5.2, \mathrm{df}=1.86, \mathrm{p}=0.002$ ), and a difference between the two groups of patients on the lie scale $(F=9.79$; df $=1.87 ; \mathrm{p}=0.002$ ).

\section{Discussion}

Patients with recurrences had a higher mean GHQ score than those experiencing first attacks. We further compared these two groups for five measures of personality and morbidity. Adjustment of the overall significance level $(p=0.05)$, using the conservative Bonferroni method' to allow for multiple comparisons, suggested a significance level of $p=0.01$ for each individual comparison. We found such a difference between the groups in the mean lie score, but the difference in the GHQ scores was less convincing. The women in both groups scored significantly higher than men in the GHQ. Studies in the UK and the USA have found evidence of greater emotionality in women, and that expression and communication of illness is more socially acceptable in women than men. ${ }^{1011}$ The GHQ not only detects potential and actual non-psychotic psychiatric illness but also gives false positive results with serious physical illness and grieving situations. ${ }^{1213}$ Painful first attack genital HSVI is a serious, albeit transient, physical illness that may result in severe grief reaction for loss of health and personal image. As for the recurrent patients who cannot accept routine counselling and reassurance, we believe that they suffer from a greater degree of nonpsychotic psychiatric illness than patients experiencing first attacks.

Other workers have found that patients with a recurrence of genital HSVI are almost totally preoccupied with concern about their sexual functioning, and have impaired interpersonal relationships, poor self image, and poor work performance. ${ }^{5}$

The differences between the sexes for the psychoticism and lie scores in this study agree with Eysenck's original normative data for the EPQ and seem to validate the results of the questionnaire in our study. When these values are compared with Eysenck's original normative data for the lie score (mean value for men aged 20-29 = 6.5 (SD = 3.88), and for women aged 20-29 = 7.17 (SD = 3.85)), the differences could be explained in several ways. For instance, patients with first attack genital HSVI are acutely psychologically shocked, and others are physically ill. In such circumstances they feel vulnerable and often guilty about their sexual activities or those of others. It is not surprising, therefore, that the mean lie scores are lower for men and women with first attack genital HSVI than the national average. An alternative explanation is that mean lie score was higher in patients with recurrences than with first attacks because the recurrers may have been trying to "fake good". When the lie score correlates highly with neuroticism, however, the lie score may represent a personality trait of "social naivety" ${ }^{8}$ The correlations in our study on these scales were $-0.08(n=53)$ $(p>0.05)$ for first attack patients, and $0.03(n=50)$ $(p>0.05)$ for those who have recurrences. It is therefore possible that patients who complain of frequent recurrences are more "socially naive" than those experiencing first attacks. The uneven distribution of socioeconomic class between the two groups, with significantly more patients in the recurrent group being of lower class, might be an indication that this group of patients is less able to make use of the early counselling provided. Such patients may not be able to negotiate the barrier of the social stigma of genital HSVI, perhaps because they are less articulate and more socially naive.

Such disadvantages would leave these patients vulnerable to negative social peer pressure about their condition. The public's perception of genital HSVI is that it is a disease of sexually promiscuous and "immoral" people, which is associated with genital cancer, neonatal deaths, and social isolation. Patients with frequent recurrences feel particularly sensitive about any mention of HSVI by their social peers, most relating to us that it was always described in negative terms or treated facetiously. This attitude has not been perpetrated by the medical profession but by the media, which have sensationalised and distorted the facts about genital HSVI. ${ }^{14}{ }^{15}$ The remedy for the shame, disgrace, and negative attitude to genital HSVI lies in altering the public attitudes to the disease. HSVI existed in the 1950s, but patients were not psychologically distressed to the same extent as today. At that time there was no generally disseminated negative 
attitude to HSVI, as there is not currently to human papillomavirus infections (which have a greater claim to morbidity and mortality).

Although asymptomatic shedding of genital HSV does occur, ${ }^{16}$ and cases of this leading to transmission have been reported, ${ }^{17}$ these events have been shown to be related to definable warning signs, such as tender inguinal lymphadenopathy and dysuria. Increased patient education and counselling should lead to an improvement in the self assessment of when to avoid sexual contact. Co-operation in preventing transmission, however, requires a sexual partner who understands and accepts the need for this. Such understanding requires a degree of emotional stability and social maturity that some of our patients who experienced recurrences lacked. A common fear in our patients was of informing a new sexual partner of their infection. Only a change in the perception of genital HSVI by patients and their prospective sexual partners will make this disclosure easier, but medical workers will need the help of the media to effect this. Without such help the negative public response can undo any good that patients derive from hearing the positive way that health workers explain genital HSVI.

\section{References}

1 Corey L, Adams HG, Brown ZA, Holmes KK. Genital herpes simplex virus infection; clinical manifestations, course and complications. Ann Intern Med 1983;98:958-72.

2 Nahmias AJ, Visintine M. Herpes simplex virus. In: Remington
JS, Kelin J, eds. Infectious diseases of the fetus and newborn. Philadelphia: WB Saunders, 1976: 156-90.

3 zur Hausen H. Human genital cancer: synergism between two virus infections or synergism between a virus infection and initiating events? Lancet 1982;ii:1370-2.

4 Reeves WC, Corey L, Adams HG, Vontver LA, Holmes KK. Risk of recurrence after first episode of genital herpes. $N$ Engl $J$ Med 1981;305:315-9.

5 Drob S, Loemer M, Lifschutz H. Genital herpes: the psychological consequences. Br J Med Psychol 1985;58:307-15.

6 Goldmeier D, Johnson A, Jeffiries D, et al. Psychological aspects of recurrences of genital herpes. J Psychosom Res 1986;30:601-8.

7 Goldberg D. Manual of the general health questionnaire. Windsor: NFER-Nelson, 1978.

8 Eysenck HJ, Eysenck SBJ. Manual of the Eysenck personality questionnaire (junior and adult). London: Hodder and Stoughton, 1981:1.

9 Godfrey K. Comparing the means of several groups. $N$ Engl J Med 1985;313:1450-6.

10 Verbrugge $M$. Females and illness. Recent trends in sex dfferences in the United States. J Health Soc Behav 1976;17:387-403.

11 Briscoe M. Sex differences in perception of illness and expressed life satisfaction. Psychol Med 1978;8:339-45.

12 Finlay-Jones RA, Murphy E. Severity of psychiatric disorder and the 30 item GHQ. Br J Psychictry 1979;134:609-16.

13 Tarnopalsky A, Hand DJ, Maclean EK, Roberts H, Wiggins RD. Validity and uses of a screening questionnaire (HQ) in the community. Br J Psychiatry 1979;134:508-15.

14 Anonymous. Herpes: the VD of the 1980s. Newsweek 1982, April 12:75-6.

15 Anonymous. The new scarlet letter. Time 1982, August 2:62-9.

16 Barton SE, Wright LK, Link CM, Munday PE. Screening to detect asymptomatic shedding of herpes simplex virus (HSV) in women with recurrent genital HSV infection. Genitourin Med 1986;62:181-5.

17 Barton SE, Davies JM, Moss VW, Tyms AS, Munday PE. Asymptomatic shedding and subsequent transmission of genital herpes simplex virus. Genitourin Med 1987;63:102-5. 